\title{
PCDD/FS LEVEL IN HUMAN ADIPOSE TISSUE OF BIENHOA RESIDENTS IN COMPARISON WITH DEVELOPED INDUSTRIAL COUNTRIES
}

\author{
Mai Tuan Anh \\ Institute of Environment and Resources, VNU-HCM \\ (Manuscript Received on August $31^{\text {th }}$, 2010, Manuscript Revised March 03'd 2010 )
}

ABSTRACT: Dioxin exhibits serious health effects when it reaches as concentration a few ppt in human body fat. Dioxin is a powerful hormone disrupting chemical. By binding to a cell's hormone receptor, it literally modifies the functioning and genetic mechanism of the cell, causing a wide range of effects, from cancer to reduced immunity, nervous system disorders, miscarriages and birth deformity. Median i-TEQ in adipose tissue of the BienHoa residents is comparable with that of the developed countries while mean i-TEQ of the Bien Hoa residents is higher in both groups, especially older people group. This group has some exceptional cases with i-TEQ value up to $1148.7 \mathrm{pg} / \mathrm{g}$. The i-TEQ value in our studies is higher than that conducted by other studies. However, our result supports a conclusion: at present, the dioxin concentration in natural environment and human bodies in Southern Vietnam is only a residue and not higher than that in developed countries.

Keywords: Agent Orange, BienHoa, CECOTOX, Dioxin, Furan, Human Adipose, IER, PCDD/Fs, i-TEQ, QuangNgai, QuangNam, Vietnam.

\section{INTRODUCTION}

Based on the published researches of many scientists (Cau HD, 2003), the strong toxicity of dioxin that after penetrating into the human body, generates several notorious features on congenital anomalies for F1 generation of those who were exposed to A.O/Dioxin. Researches on bio-genetic showed that there existed a chromosomal aberrations such as the defects, the gaps, breaks, dicentric chromosomes, the translocation, the ring, the miniature chromosomes, and the chromatid sisters exchanges (Tuyen et al, 1983; Trung et al, 1995). The chromosomal aberrations were one of the causes of cancer, and of the reproductive accidents during the embryonic phase.
Chromosome aberrations in the germ cells (in female, male) might transmit to subsequent generations.

For above reason, human adipose tissue is an important matrix to understand the influence of dioxins on human health (especially adipose tissue of pregnant women because it is directly related to reproduction and next generation). Because the $\mathrm{PCDD} / \mathrm{Fs}$ are lipophilic compounds, when they penetrate into human body via direct/indirect contact they accumulate mainly in human body with high lipid content. Their concentration in human tissue is very important factor to evaluate the critical toxic level for human health and for risk assessment. 
However, study of dioxin residue in human adipose tissue is not simple. It is very difficult to implement and subject to many factors such as:

- Time and budget constraints;

- The difficulties in getting sampling permit from various sources

With the help of DongNai Polyclinic, we have done the sampling on pregnant women who went through a surgery within period of from March 2004 to December 2004. The adipose tissue samples were taken under bally skin with weight varied from 0.5 to $8 \mathrm{~g}$ (depends on actual circumstances). After sampling, the samples were stored in fridge at $25^{\circ} \mathrm{C}$ until analysis.

Within the scope of the collaboration project between Swiss (Cecotox) and VietNam (IER), we had analyzed 90 out of 200 samples taken. The samples were pre-treated and analyzed in Cecotox Lab and intertested in Carso Lab (Laboratoire Santé Environnement et Hygiène de Lyon - a certified lab on dioxin analysis in France).

The samples were coded as $\mathrm{ADi}(\mathrm{i}=1-$ 91) and analyzed by the certified method described below.

\section{MATERIALS AND METHODS}

The analytical procedure is the certified methods proposed by US EPA (IARC,1991; US.EPA -Method 1613, 1994; Simon, $M$ and Wakeford, B.J., 2000) modified to adapted with available conditions in the laboratory: The PCDD/Fs analysis was performed using an isotope dilution technique. Samples were extracted by appropriate solvents (dichloromethane/n-hexane 1:1); then clean-up by chromatography column (multilayer silicagel column, florisl and alumina); in the end quantified by GC/HRMS.

* Extraction

Normally biological samples are in the heterogeneous form that not facilitated for extraction (the solvent penetration into the structure of the matrix is very difficult). So, before extraction, the biological sample should be treated to change in free-flowing form. Generally, the samples are grounded with anhydrous sodium sulfate by a grinder. The samples are grounded with anhydrous sodium sulfate by a grinder (the $\mathrm{Na}_{2} \mathrm{SO}_{4}$ quantity mixed is normally equal 3-4 times of test portion weight - about $20 \mathrm{~g}$ ).

As solvent for extraction we chose the mixture dichloromethane/n-hexane 1:1 (DCM/n-Hex 1:1). The extraction time is one night (8-12h) only.

* Sample preparation - the acid treatment

The acid treatment is commonly used to destroy the inorganic matrix of the samples and to make it easy to extract PCDD/Fs. We applied some techniques to shorten the analysis time:

- Use the $\mathrm{HCl} 3 \mathrm{M}$ instead of the $\mathrm{H}_{2} \mathrm{SO}_{4}$, conc. and shorten the acid treatment to 2-3h only;

- Use dry hot air instead of oven for solid+filter.

* Sample preparation - the purification by $\underline{\text { multilayer columns }}$ 
The concentrated extract containing interesting compounds is again cleaned-up by several chromatography columns. For biological samples we use only two columns: silica mix column and alumina basic column. Two columns are connected and all elute from silica column is passed onto second column; then the silica mix column is taken out and the purification steps are continued with alumina basic column.

- Silica mix column: we use the combination of three silica types, including activated silica (neutral silica activated by heating), basic silica (silica mixes with $\mathrm{CsOH}$ ) and acidic silica (silica mixed with $\mathrm{H}_{2} \mathrm{SO}_{4}$ conc.). The extract is passed through silica combined column and the fatty compounds are retained in the silica structure and the interested compound are eluted by a suitable solvent (n-hexane).

- Alumina column: by utilization of alumina column we can separate the PCDD/Fs from almost interfering compounds such chlorinated benzenes, PCBs and higher chlorinated diphenyls ethers. These compounds are eliminated in the first fractions (lower polar solvent mixture of n-hexane/DCM (2:98)

The sample was eluted with:

i) $10 \mathrm{~mL}$-hexane

ii) $10 \mathrm{~mL}$ n-hexane/dichloromethane $(92: 8)$

iii) $15 \mathrm{~mL}$ n-hexane/dichloromethane (2:3)

iv) $20 \mathrm{~mL}$ dichloromethane

Two last elutes were taken and analyzed for PCDD/Fs concentration. the extract containing interested compounds should be concentrated to sufficiently small volumes (as low as a few microlitres, $\mu \mathrm{L}-$ usually $10-50 \mu \mathrm{L}$ ). By this way the concentration of $\mathrm{PCDD} / \mathrm{Fs}$ in our extract is multiplied to $1.000 .000-2.000 .000$ times and reached the detection limit of analytical equipment used for analyses GC/HRMS

* PCDD/Fs identification by GC/HRMS

The HRMS used for this purpose is GC Agilent 6890N coupled with HRMS Micromass Autospect Ultima, with the resolution more than 10,000 and MS mode EISIM. Used column was Agilen DB-5 MS 60m $\times 0.25 \mathrm{~mm} \times 0.1 \mathrm{um}$, connected with $1 \mathrm{~m}$ precolumn (Restek ). The temperature program: $180{ }^{\circ} \mathrm{C}(2 \mathrm{~min})$---> $220{ }^{\circ} \mathrm{C}\left(4{ }^{\circ} \mathrm{C} / \mathrm{min}, 12 \mathrm{~min}\right)$ --> $235{ }^{\circ} \mathrm{C}\left(5{ }^{\circ} \mathrm{C} / \mathrm{min}, 9 \mathrm{~min}\right)$---> $310{ }^{\circ} \mathrm{C}(9$ $\left.{ }^{\circ} \mathrm{C} / \mathrm{min}, 1 \mathrm{~min}\right)$. The result was calculated based on a set of 5 calibration standards $\mathrm{C} 1-\mathrm{C} 5$ (Wellinton) and internal standard including 17 isotope 2,3,7,8-PCDD/Fs.

\section{RESULT AND DISCUSSION}

3.1.PCDD/Fs concentration in human adipose tissue of BienHoa residents

The PCDD/Fs concentration in adipose tissue of BienHoa residents are presented in Table 1 and Fig. 1 below.

\section{Trang 94}



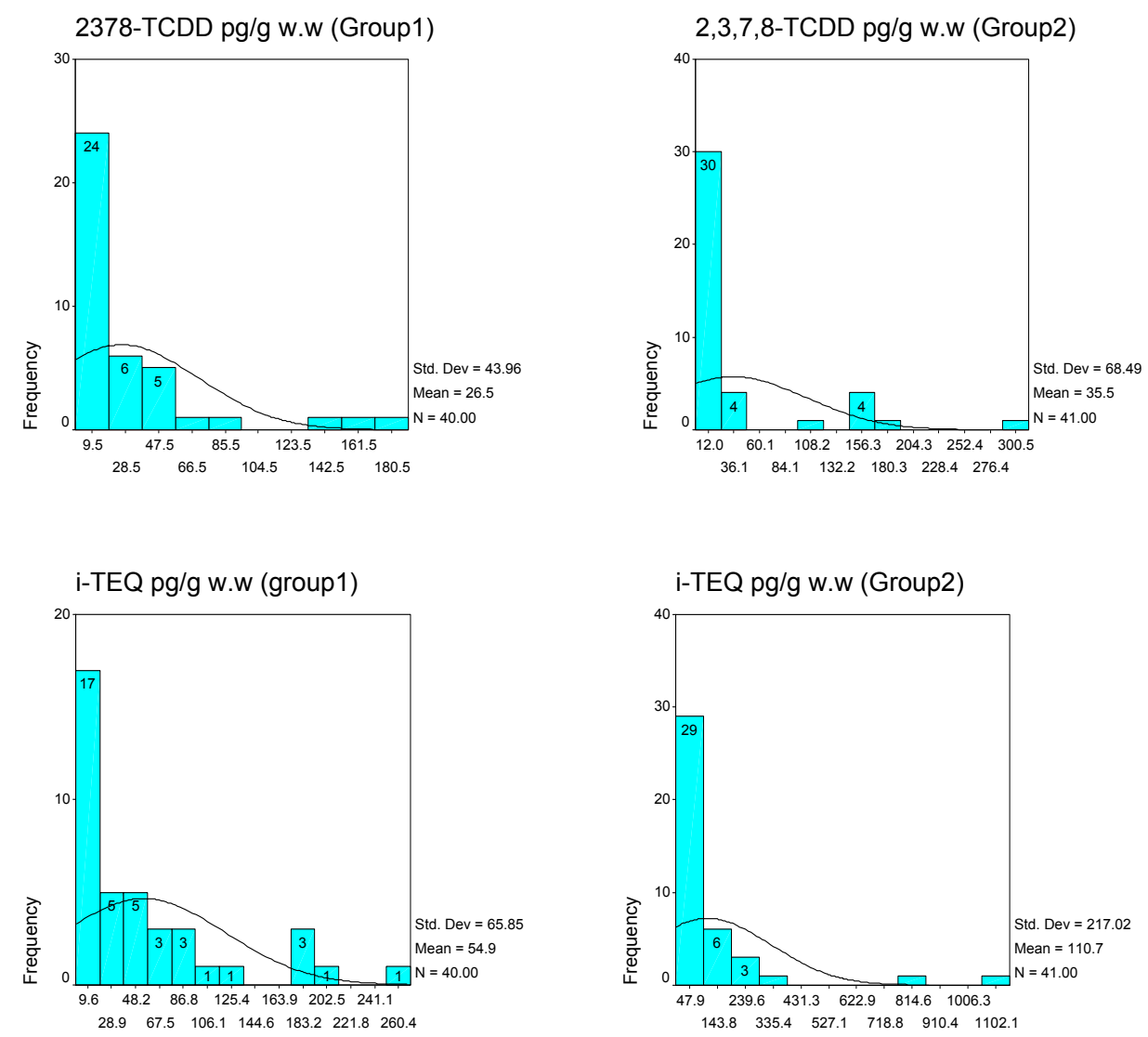

Figure 1. Distribution of 2,3,7,8-TCDD concentration and i-TEQ in samples of two groups

Fig. 1 shows that the distributions of 2,3,7,8TCDD concentration and i-TEQ of two groups. Group1 has highest density on the left (more cases with low 2,3,7,8-TCDD and i-TEQ), then gradually decreased to the right; group2 has highest density on the left, but its density in the middle increases a little bit (6/41 cases $-15 \%)$. The median values of 2,3,7,8-TCDD concentration and $\mathrm{i}-\mathrm{TEQ}$ values of two groups are equal, but the mean values of group2 are higher for both 2,3,7,8-TCDD and i-TEQ. That means group2 has more exceptional cases with higher values than upper bound as showed in the Fig. 2 below.

With regard to 2,3,7,8-TCDD - the most toxic compound of $2,3,7,8-\mathrm{PCDD} / \mathrm{Fs}$, it is detected in $43 / 81$ cases (53\%) of analyzed samples. This indicates 2,3,7,8-TCDD is a critical component of $\mathrm{PCDD} / \mathrm{Fs}$ contamination in adipose tissue of BienHoa residents. Its contribution to i-TEQ value is used for evaluation of the source of PCDD/Fs which will be discussed later. 
Table1. Statistic comparison between two groups in TCDD concentration and i-TEQ (pg/g w.w)

\begin{tabular}{ccccc}
\hline & $\begin{array}{c}\text { Group1 } \\
\text { (age: } 19-30)\end{array}$ & \multicolumn{2}{c}{$\begin{array}{c}\text { Group } 2 \\
\text { (age: } 31-59)\end{array}$} \\
\hline $\mathrm{N}$ & $2378-T C D D$ & $i-T E Q$ & $2378-T C D D$ & $i-T E Q$ \\
Mean & 40 & 40 & 41 & 41 \\
Median & 26.5 & 54.9 & 35.5 & 110.7 \\
Std. & 1.7 & 27.0 & 1.7 & 26.6 \\
Deviation & 44.0 & 65.8 & 68.5 & 217.0 \\
Range & 177.6 & & & 1148.0 \\
Minimum & nd & 255.5 & 300.0 & 0.7 \\
Maximum & 177.6 & nd & nd & 1148.7 \\
\hline
\end{tabular}

Note: nd-non-detectable
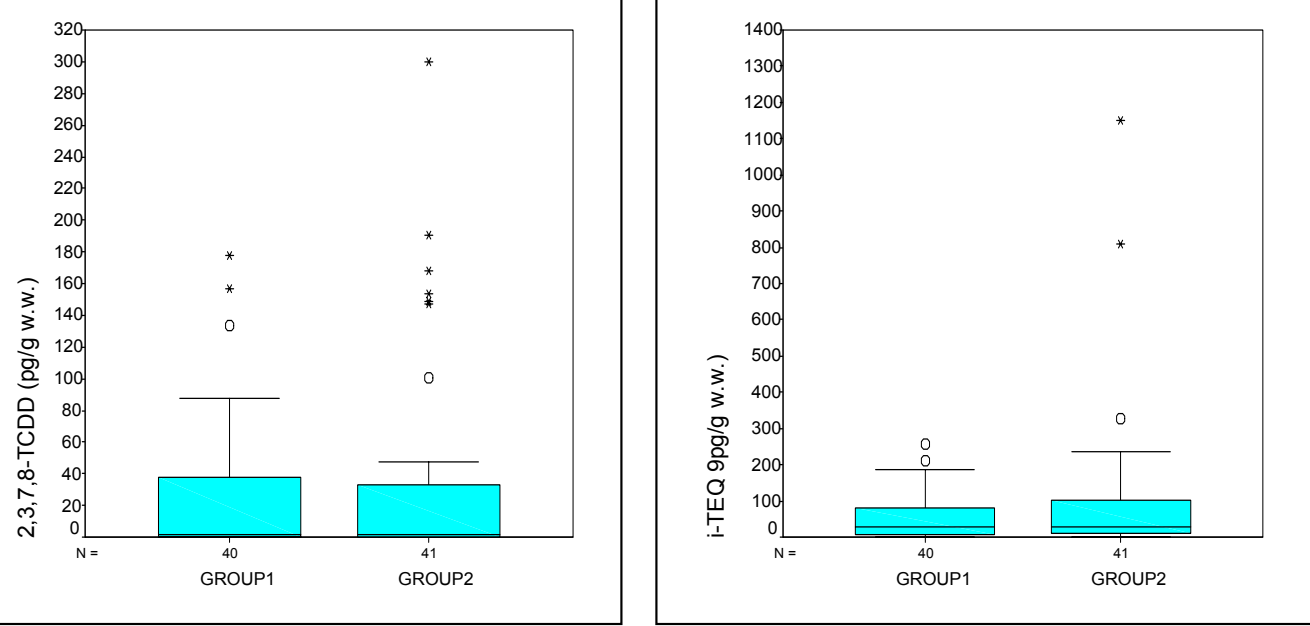

Figure 2. PCDD/Fs levels in human adipose samples of BienHoa residents based on i-TEQ and 2,3,7,8-TCDD concentration

We also analyzed 9 adipose samples of nonBienHoa residents (see Table 2). Because these people were not from Bien Hoa city, study results presented here are only for reference only without statistic analysis. 2,3,7,8-TCDD was detected in 6/9 samples. Two samples having highest 2,3,7,8,-TCDD concentration (AD16 and AD41) were from two women with relative high age (35 and 40). It is interesting that both were born and lived in central of
VietNam (QuangNgai and QuangNam Provinces) - areas affected seriously by Agent Orange and other chemicals during the war. Though in fact we cannot conclude anything from these two samples as they are not representative at all, we suggest relevant organizations such Committee 33 or Division 10-80 to consider and carry-out more studies in these areas.

\section{Trang 96}


Table 2.PCDD/Fs concentration in human adipose tissue of non-BienHoa residents (pg/g w. w)

\begin{tabular}{|c|c|c|c|c|c|c|c|c|c|}
\hline Sample & AD5 & AD10 & AD16 & AD17 & AD33 & AD37 & AD40 & AD41 & AD79 \\
\hline Age & 39 & 34 & 35 & 20 & 36 & 32 & 23 & 40 & 29 \\
\hline \multicolumn{10}{|l|}{ Isomer } \\
\hline 2378-TCDD & nd & nd & 773.4 & $\mathrm{Nd}$ & 10.2 & 55.7 & 51.3 & 65.8 & 1.7 \\
\hline 12378-PeCDD & nd & nd & nd & 47.0 & 19.1 & nd & nd & 374.7 & nd \\
\hline 123478-HxCDD & nd & nd & 63.3 & 9.3 & nd & nd & nd & nd & nd \\
\hline 123678-HxCDD & nd & nd & 468.8 & $\mathrm{Nd}$ & nd & nd & nd & nd & nd \\
\hline 123789-HxCDD & nd & nd & 342.2 & $\mathrm{Nd}$ & nd & nd & nd & nd & nd \\
\hline $1234678-$ & 14.6 & 8.0 & nd & 176.3 & 29.5 & 109.2 & nd & nd & nd \\
\hline \multicolumn{10}{|l|}{ HpCDD } \\
\hline OCDD & 10.1 & nd & 3125.1 & 10.8 & 26.6 & 917.9 & 561.1 & nd & nd \\
\hline 2378-TCDF & 0.6 & 0.3 & 12.0 & $\mathrm{Nd}$ & nd & nd & nd & nd & nd \\
\hline 12378-PeCDF & nd & nd & nd & $\mathrm{Nd}$ & nd & nd & nd & nd & nd \\
\hline 23478-PeCDF & 1.7 & 2.4 & 8.0 & 9.4 & 8.1 & nd & nd & 37.8 & nd \\
\hline 123478-HxCDF & nd & nd & 375.0 & $\mathrm{Nd}$ & 12.3 & 107.5 & 112.9 & nd & 40.9 \\
\hline 123678-HxCDF & nd & nd & nd & $\mathrm{Nd}$ & nd & 116.0 & 158.1 & nd & nd \\
\hline 123789-HxCDF & 0.1 & nd & nd & 0.7 & nd & 72.6 & nd & 27.8 & nd \\
\hline 234678-HxCDF & nd & nd & nd & 2.8 & nd & 70.3 & nd & nd & nd \\
\hline $1234678-$ & nd & nd & nd & $\mathrm{Nd}$ & 8.1 & 80.3 & nd & nd & nd \\
\hline \multicolumn{10}{|l|}{$\mathrm{HpCDF}$} \\
\hline $1234789-$ & 0.6 & 0.6 & nd & $\mathrm{Nd}$ & nd & 100.6 & nd & nd & nd \\
\hline \multicolumn{10}{|l|}{$\mathrm{HpCDF}$} \\
\hline OCDF & nd & nd & 857.5 & 6.6 & 30.9 & 460.9 & 423.3 & 255.5 & nd \\
\hline i-TEQ & 1.1 & 1.3 & 903.9 & 54.7 & 24.8 & 39.7 & 27.2 & 396.3 & 4.1 \\
\hline
\end{tabular}

Note: nd-non-detectable

3.2.PCDD/Fs level in human adipose of

BienHoa residents in comparison with others

There is neither suggested value not value limit for PCDD/Fs concentration in human tissue. In fact we have very few documents related to this subject in VietNam. Therefore we can only compare the PCDD/Fs level in human adipose of BienHoa residents with results obtained in other countries which are presented in Table 3
Table 3 shows that median i-TEQ in adipose tissue of BienHoa residents is comparable with the industrial countries while mean i-TEQ of Bien Hoa residents was higher among both groups, especially for older people group (group2). This group even has some exceptional cases with i-TEQ value up to $1148.7 \mathrm{pg} / \mathrm{g}$. 
Table 3.Our result in comparison with results obtained by others

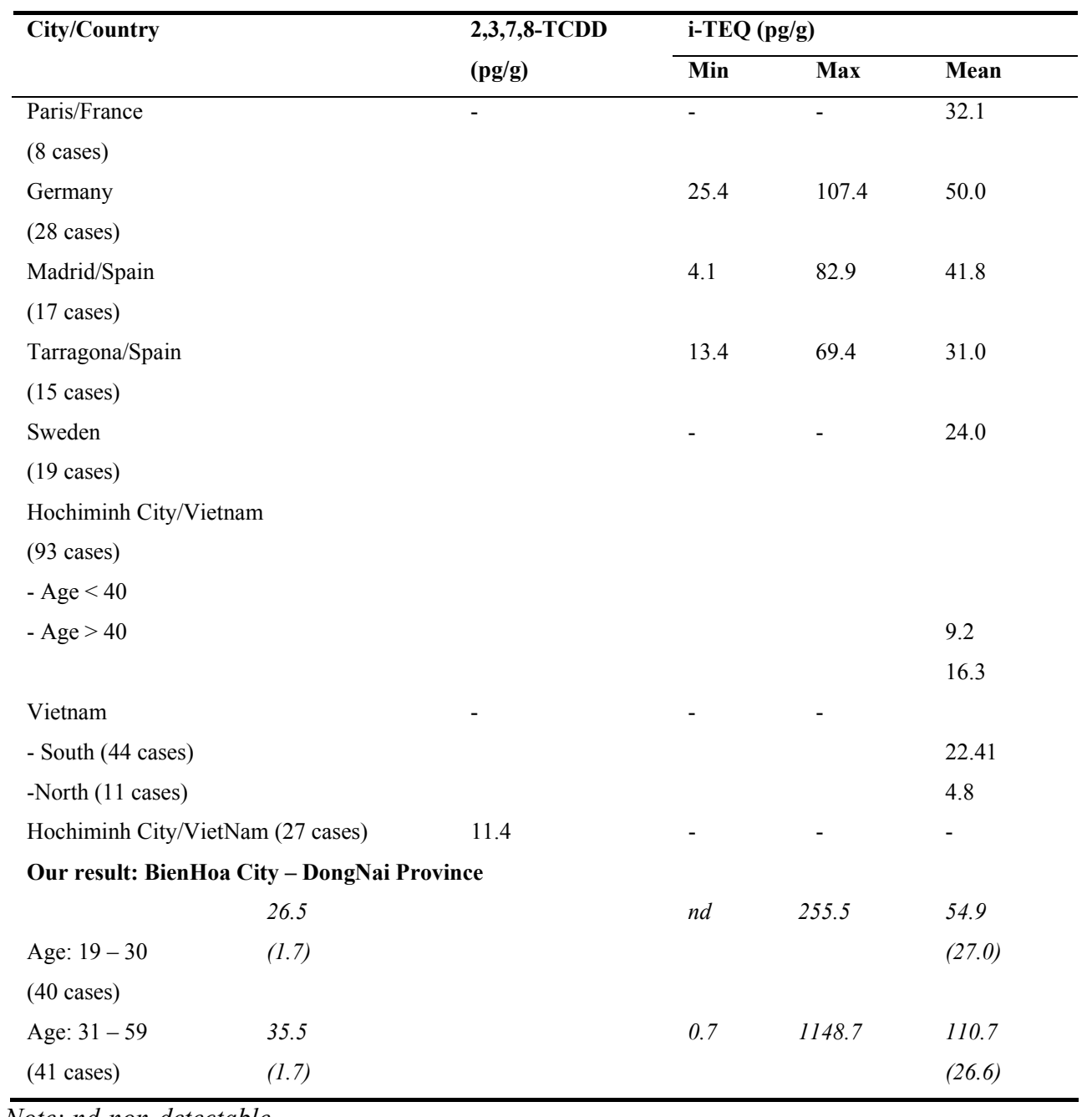

Note: $n d$-non-detectable

Values in parenthesis: median values

Our results show higher i-TEQ value than other studies. However, the general results support conclusion of previous studies: at present, the dioxin concentration in natural environment and human bodies is only a residue and not higher than that in developed countries.
3.3.Comparison of human adipose samples

Using PCA (Principle Component Analysis) for two groups of BienHoa residents we obtained the results showed in Fig.3 and Fig.4. For younger group (group1 - Fig.3), the biggest group of samples (lower-left) is interacted mostly by OCDD, HxCDF and partially by

\section{Trang 98}


OCDF; second group (lower-right) contains the samples interacted mostly by TCDF, HpCDF and partially by TCDD and PeCDF; third group (upper-right) contains the samples interacted by HpCDD and HpCDF; last group (upper-left) contains the samples interacted by HxCDD and PeCDD.

For older group (group2 - Fig.4), there are two big groups: one in the lower-left contains the samples interacted mostly by OCDD, OCDF and partially by TCDF; another in upper-right contains the samples interacted by HpCDF, HxCDF and PeCDD. Smaller group of samples (upper-left) contains the samples interacted mostly by HpCDD and partially by HxCDD. The rest samples (lower- right) are very dispersive, interacted by TCDD and PeCDF.

When combining Fig.3 and Fig.4, we see that OCDD, OCDF and TCDF are important factors to separate the human adipose samples based on $\mathrm{PCDD} / \mathrm{Fs}$ relative profiles.

Using PCA for $\mathrm{PCDD} / \mathrm{Fs}$ relative i-TEQ profiles, we obtained the result shown in Fig.5 and Fig.6. The PCA was done with regard to 2,3,7,8-TCDD - the most toxic compound which is also found to be originated from Agent Orange/Dioxin.

Group1 showed more concentration of samples by interaction of 2,3,7,8-TCDD, 2,3,7,8-TCDF and 1,2,3,7,8-PeCDF while group2 was dispersive with less interaction of 2,3,7,8-TCDD and more interaction of hexaand penta- 2,3,7,8-substituted $\mathrm{PCDD} / \mathrm{Fs}$ as showed in Fig.6.

When combining Fig.5 and Fig.6, we can conclude that $2,3,7,8-\mathrm{TCDD}$ takes a more important part of i-TEQ at younger people than at older people.

However this conclusion should be reexamined in a larger scale study with more supporting data among well selected group of people. 
Comparison of human adipose samples by PCDD/Fs relative profiles (Group1 - Age 19-30) -Scores t[Comp. 1]/t[Comp. 2]

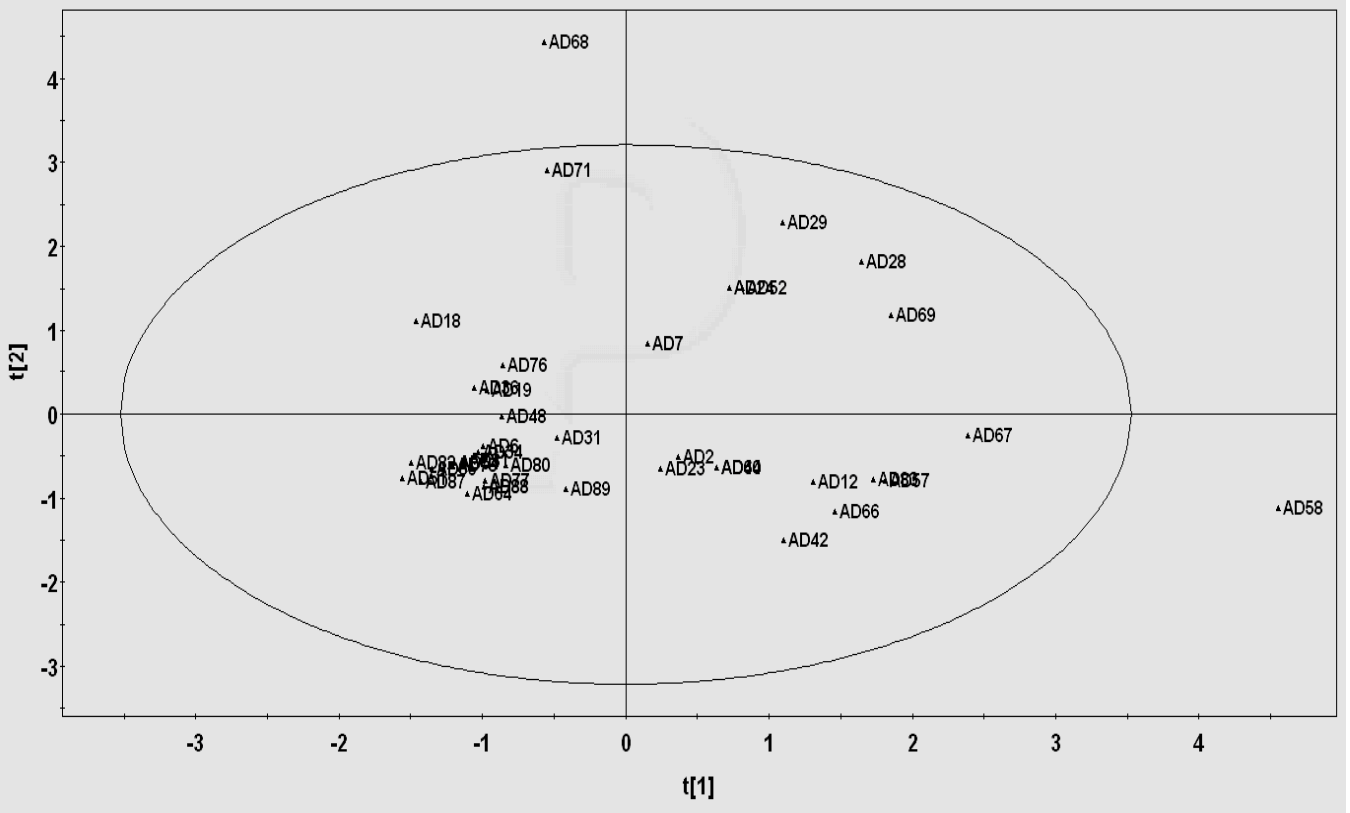

Comparison of human adipose samples by PCDD/Fs relative profiles (Group1 - Age 19-30) -Loading p[Comp. 1]/p[Comp. 2]

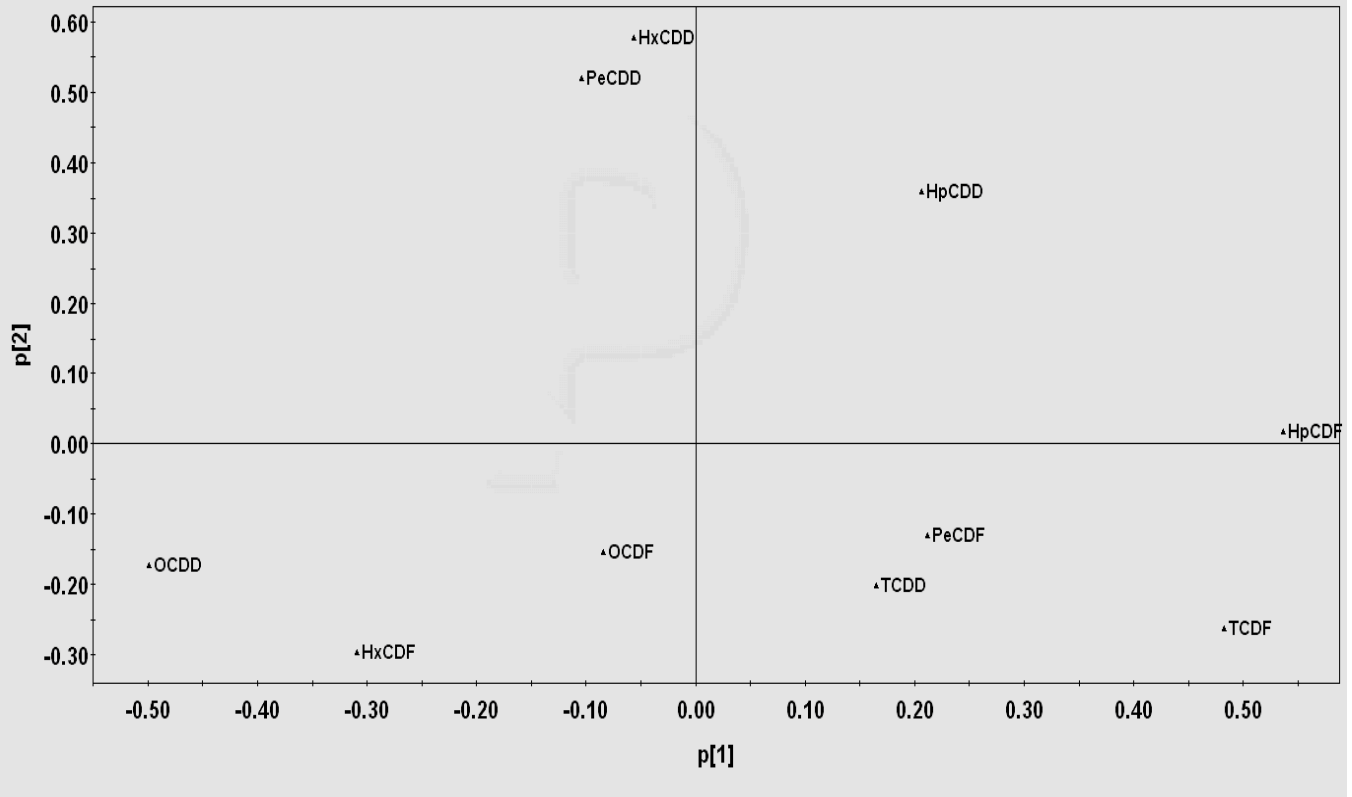

Figure 3. CA analysis based on PCDD/Fs relative profiles (group1 - age 19-30)

\section{Trang 100}



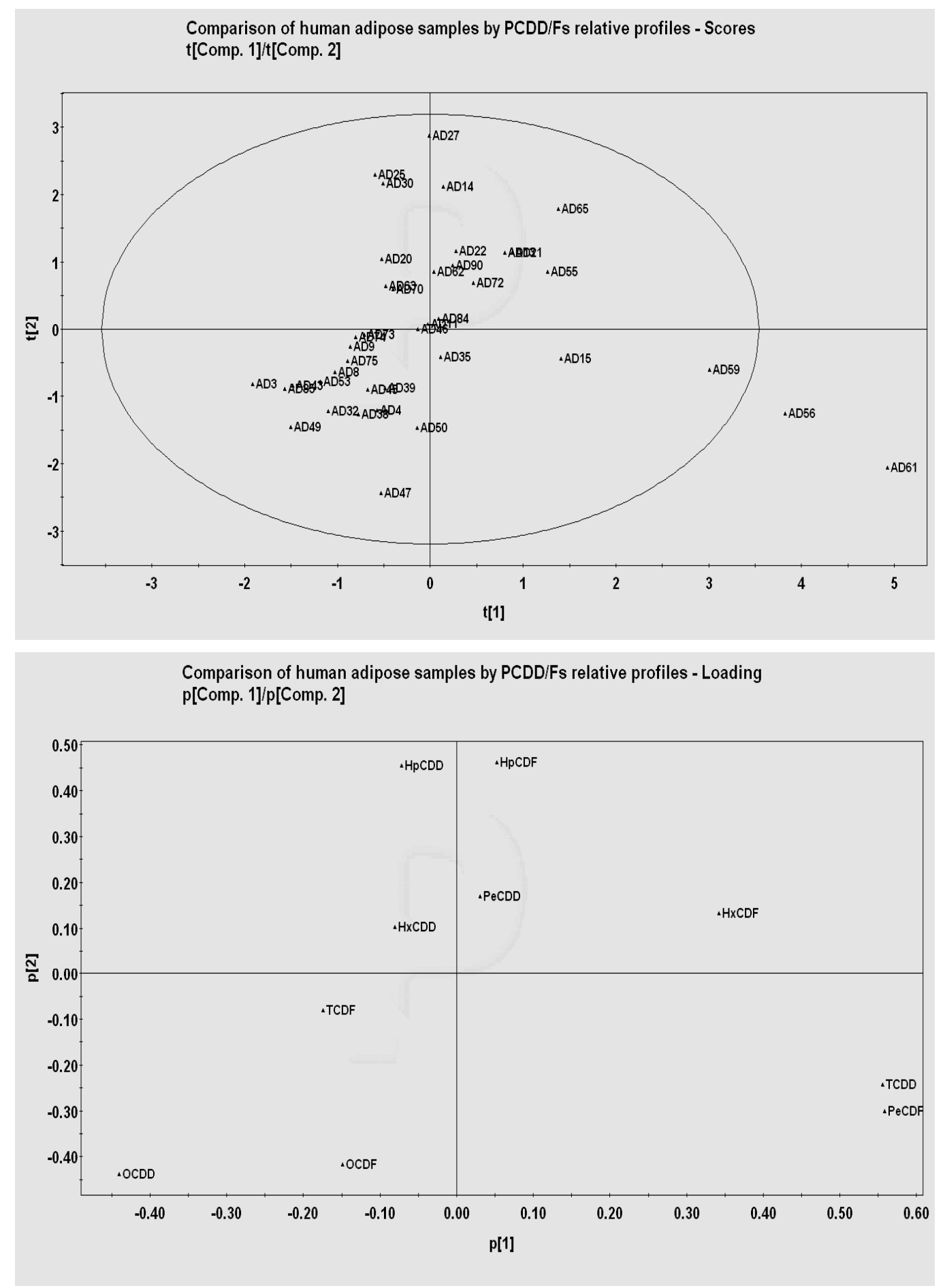

Figure 4. PCA analysis based on PCDD/Fs relative profiles (group2 - age 31-59) 

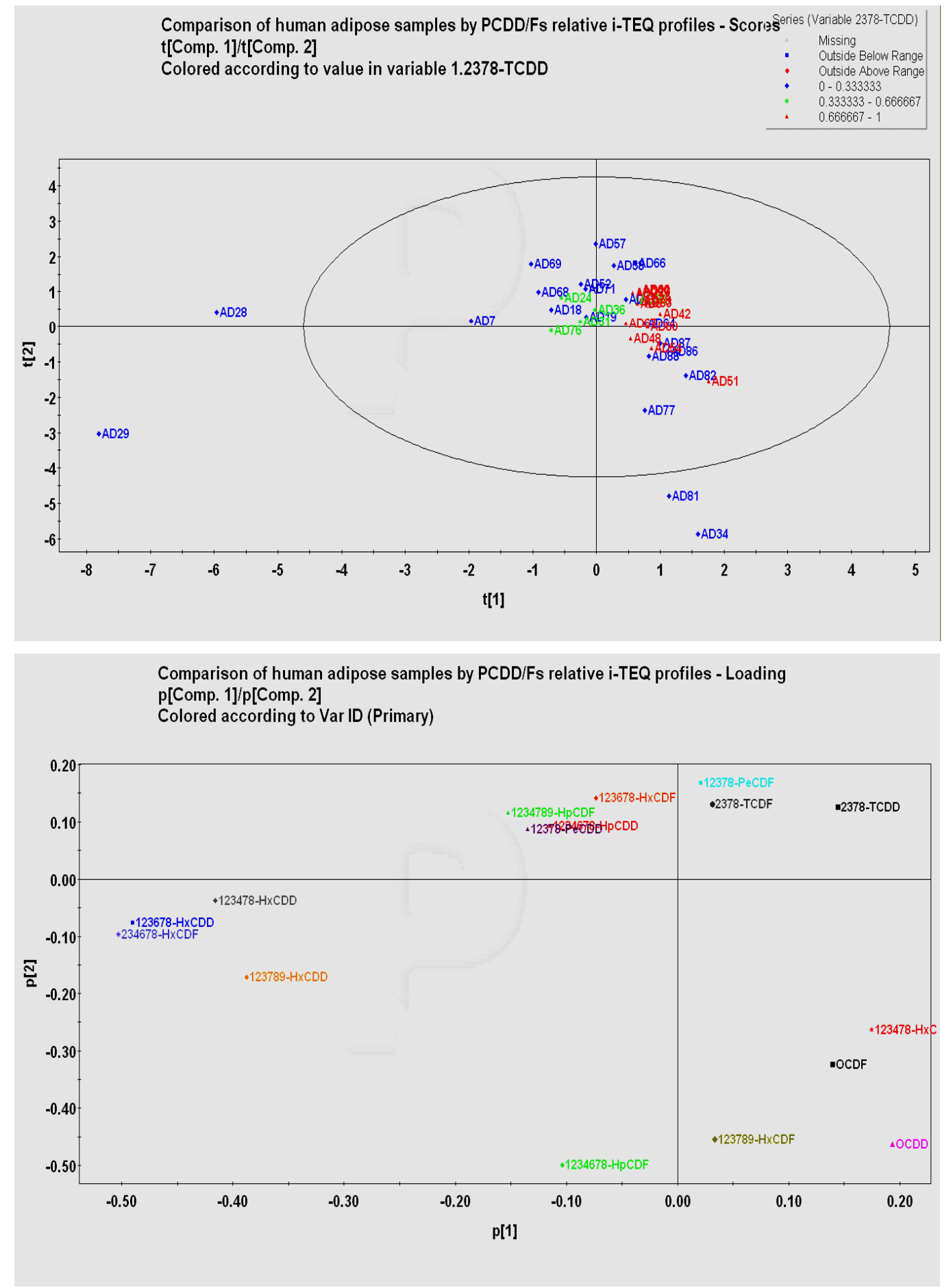

Figure 5. PCA analysis based on PCDD/Fs relative i-TEQ profiles (group1 - age 19-30)

\section{Trang 102}


Comparison of human adipose samples by PCDD/Fs relative i-TEQ profiles (Group2) pries (Variable 2378-TCDD) t[Comp. 1]/t[Comp. 2]

Colored according to value in variable .2378-TCDD

- Outside Below Range

- Outside Below Range

- Outside Above Ranc 0.33015

$0-0.332015$ $0.664029-0.996044$

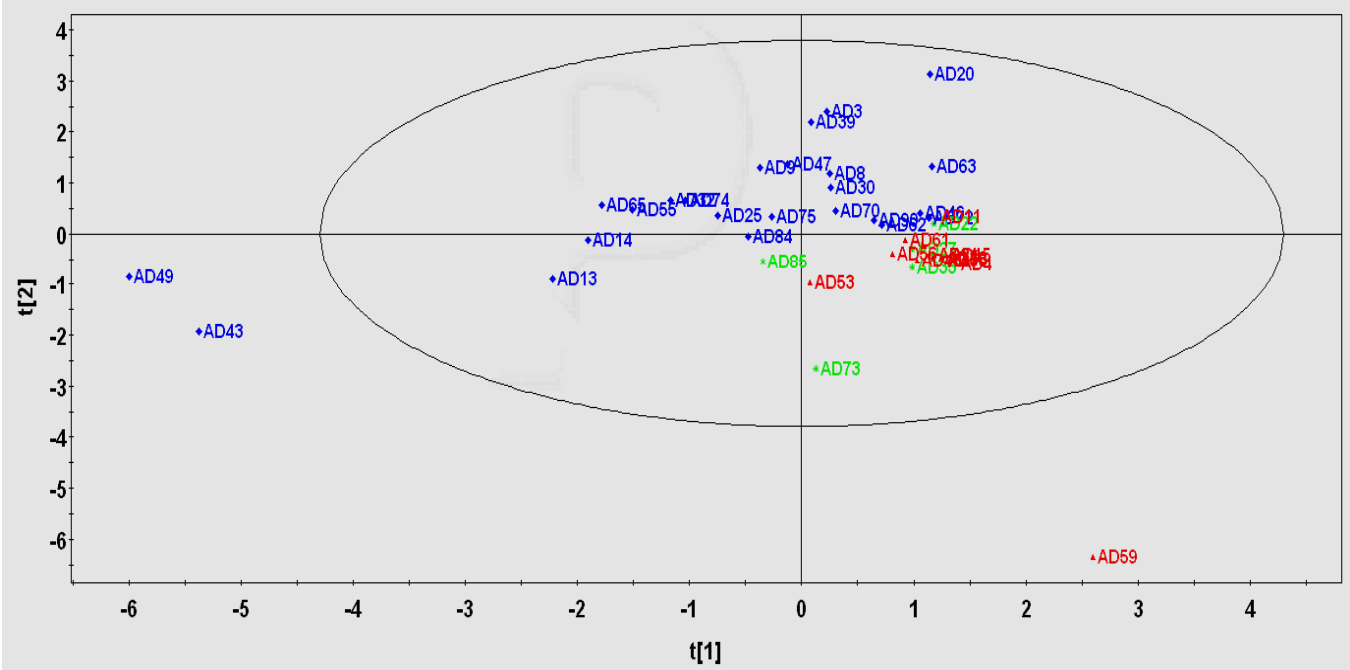

Comparison of human adipose samples by PCDD/Fs relative i-TEQ profiles (Group2) p[Comp. 1]/p[Comp. 2] Colored according to Var ID (Primary)

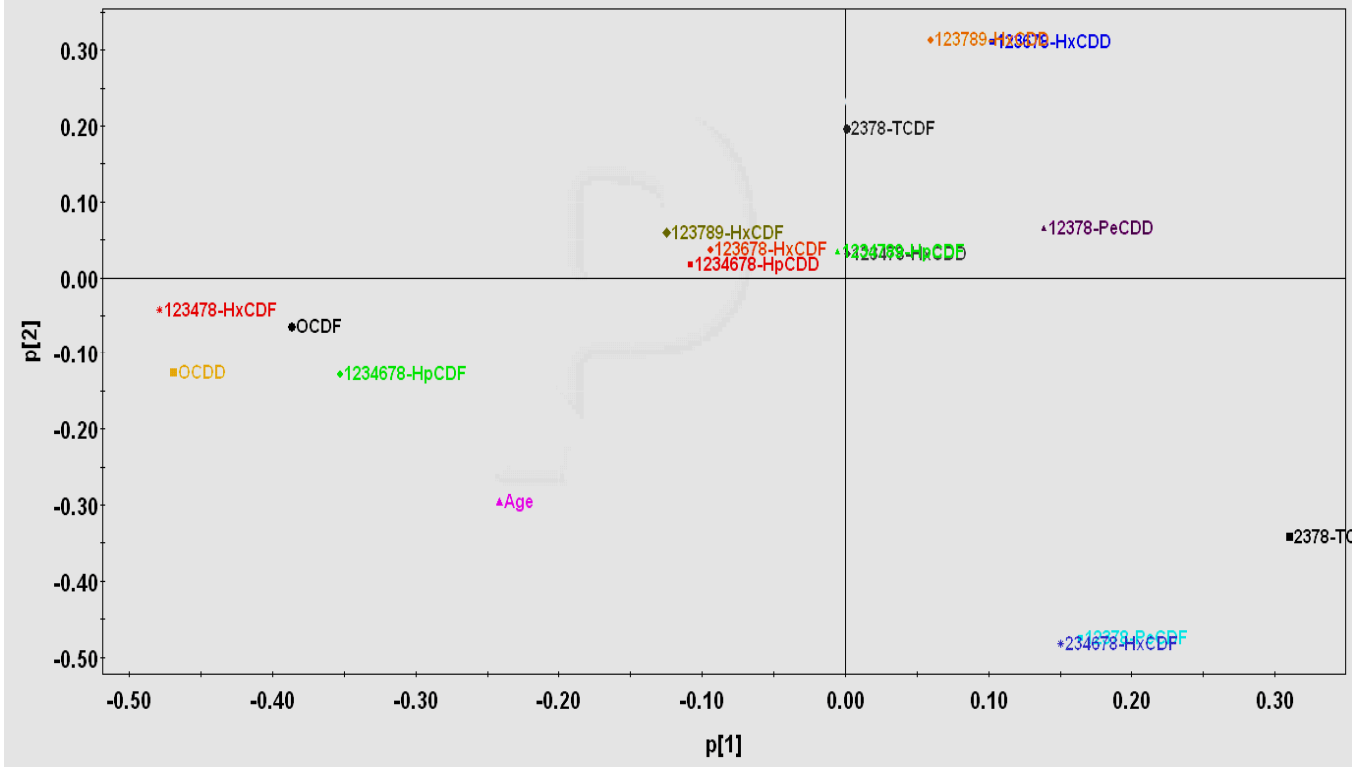

Figure 6. PCA analysis based on PCDD/Fs relative i-TEQ profiles (group2-age 31-59) 


\section{CONCLUSION}

The PCDD/Fs concentration based on iTEQ value in human adipose of BienHoa residents is comparable with the industrial countries. From toxicity point of view the residue of 2,3,7,8-TCDD in women body (49/90 cases) could affect negatively on young generation, especially for some cases having high concentration. The result of PCA showed that this compound affects more in $\mathrm{PCDD} / \mathrm{Fs}$ profiles of younger people than older. Since $2,3,7,8$-TCDD is the most toxic compound and related to the Agent Orange/Dioxins from the war, so a large-scale investigation on selected group of people (people affected/having diseases related to Agent Orange/Dioxins) should be done to confirm this conclusion.

However the research scale is small and only a section research due to limitation of budget and time, but the obtained result positively contributes to National Dioxin Research Plan.

Acknowledgement: We would like to thank the Swiss Agency for Development and Cooperation (SDC) for financial support, the Department of Geotechnics - Polytechnic University of Hochiminh City for sampling assistance, the Laboratoire Santé Environnement Hygiene de Lyon (Carso) for analytical method validation and the local governmental institutions for experiments collaboration.

\section{MỨC TỒN DƯ CỦA CÁC HỢP CHẤT DIOXIN/FURAN TRONG MÕ̃ CỦA CÁC CỦ DÂN BIÊN HÒA SO VỚI CÁC QUỐC GIA PHÁT TRIỂN}

\section{Mai Tuấn Anh}

Viện Môi trường \& Tài nguyên, ĐHQG-HCM

TÓM TÁT: Dioxin gây ảnh hưởng nghiêm trọng đến sức khỏe con ngườ ngay cả khi hiện diện trong mỡ người ở nồng độ một vài phần ngàn tỷ (ppt). Dioxin là chất hóa học phá hủy mạh các nội tiết tố. Bằng cách gắn vào thu thể nội tiết tố của tế bào dẫn đến sụ biến đổi co chế hoạt động và di truyền của tế bào, gây nên hàng loạt các hiệu ứng xấu: tù ung thu cho đến giảm khả năng miễn dịch, rối loạn hệ thần kinh, sẩy thai và các dị tật bẩm sinh. Mức tồn du Dioxin trong mõ của các cu dân Biên Hòa thể hiện qua độ độc tuơng tuơng (i-TEQ) ở mức sánh ngang với các nuớc phát triển, tuy nhiên nếu tính trung bình thì giá trị này cao hơn ở cả hai nhóm nghiên cứu, đặc biệt là nhóm người lớn tuổi. Nhóm này có một số truờng hợp đặc biệt với giá trị i-TEQ lên đến 1148,7 pg/g. Giá trị i-TEQ trong nghiên cứu của chúng tôi cao hơn một số nghiên cứu đã thực hiện truớc đây. Mặc dù vậy kết quả nghiên cứu góp phần khẳng định: ở thời điểm hiện tại, nồng độ Dioxin trong môi truờng và con nguời Việt Nam chỉ là du lương và không cao hơn các nước phát triển.

Tù khóa: Agent Orange, BienHoa, CECOTOX, Dioxin, Furan, Human Adipose, IER, PCDD/Fs, i-TEQ, QuangNgai, QuangNam, Vietnam

\section{Trang 104}




\section{REFERENCES}

[1]. AAFV, L'agent orange au Vietnam: Crime d'hier -Tragédie d'aujourd'hui. Paris: Éditions Tirésias, (2005).

[2]. Anh MT, Vu DT, Hang, H.T.M., Tarradellas, J., deAlencastro, L.F., and Grandjean, D. Dioxin contamination in the soil - south Vietnam. Organohalogen Compounds 66: 3670-3676, (2004).

[3]. Cau HD, Environment and human health in Vietnam - Years after the Ranch Hand Operation, Hanoi. (2003).

[4]. Cau HD, Hung TM, Dung PT, and Anh NT, The consequences of herbicides and defoliants on nature and Man. HaNoi: Division 10-80, (1993).

[5]. DETR, Compilation of EU Dioxin Exposure and Health Data: Task 5 Human Tissue and Milk Levels. UK Department of the Environment: Transport and the Regions (DETR). (1999).

[6]. Division10-80, 1st International Conference on Herbicides in war - the Long-term effects on Man and Nature. HaNoi: Division 10-80, (1983).

[7]. Division10-80, Report on all studies from 1980 to 2000: The Consequence of toxic chemicals used by US.Force during the War in Vietnam, Division10-80, HaNoi, (2000).

[8]. IARC, (International Agency for Research on Cancer), Environmental Carcinogens Methods of Analysis and Exposure Measurement; Vol. 11 -
Polychlorinated Dioxins and Dibenzofurans.(1991).

[9]. Petersen A, Compilation of EU Dioxin Exposure and Health Data: Task 5 - Human Tissue and Milk Levels. Oxfordshire: AEA Technology plc, (1999). [10]. Phiet PH, Phuong NTN, Tan V, Schecter A, Dioxin level in individual fat tissue specimens of 93 patients living in South VietNam. Medicine - Hochiminh City 4(1): 187-190.(1997).

[11]. Schecter A, Dai LC, Paepke O, Prange J, Constable JD, Matsuda M, Thao VD, and Piskac AL, Recent dioxin contamination from Agent Orange in residents of a southern Vietnam city. J. Occup. Environ. Med. 43: 435, (2001).

[12]. Simon, M and Wakeford, B.J. Multiresidue method for determination of polychlorinated dibenzo-p-dioxins, polychlorinated dibenzofurans and nonortho substitued polychlorinated biphenyls in wildlife tissue by HRGC/HRMS.

Quebec, Canada, National Wildlife Research Centre - Canadian Wildlife Service: 42pp.(2000).

[13]. Trung, C.B., Dieu, V.V., et al, Confusion of chromosomes in people directely exposured to toxic chemicals in Souther Vietnam during the war. Hanoi, University of Medicine - Hanoi.(1995).

[14]. Tuan Anh M, Thanh Vu D, Joseph T, Luiz FA, Dominique G, Dioxin contamination in soils of Southern 
Vietnam. Chemosphere 67: 1802-1807, (2007).

[15]. Tuyen, B.C., Thai, T.T., Binh, P.X., Hoa, B.K., Lien, P.T., and Lieu, V.T. The consequences of herbicides and defoliants on vietnameses. Hanoi, University of Medicine - Hanoi. (1983).

[16]. US.EPA, Method 1613 - Tetrathrough Octa-Chlorinated Dioxins and Furans by Isotope Dilution HRGC/HRMS. (1994). 